\title{
Studies on Intestinal Absorption of Sulpiride (1): Carrier-Mediated Uptake of Sulpiride in the Human Intestinal Cell Line Caco-2
}

\author{
Kazuhiro Watanabe, ${ }^{*}, a$ Tetsuya SAmano, ${ }^{a}$ Kazuaya Terada, ${ }^{a}$ Tetsuya Endo, ${ }^{b}$ Masakatsu SAKata, ${ }^{b}$ and \\ Juichi SATO ${ }^{a}$ \\ ${ }^{a}$ Hokkaido College of Pharmacy; 7-1 Katsuraoka-cho, Otaru, Hokkaido 047-0264, Japan: and ${ }^{b}$ Faculty of \\ Pharmaceutical Sciences, Health Sciences University of Hokkaido; 1757 Ishikari-Tobetsu, Hokkaido 061-0293, Japan. \\ Received January 30, 2002; accepted March 23, 2002
}

\begin{abstract}
We investigated whether the uptake of a specific antipsychotic agent, sulpiride, in Caco-2 cells is mediated by a carrier-mediated system. Caco-2 cell monolayers were cultured in plastic culture dishes and uptake and efflux studies were conducted. The determination of sulpiride was performed by HPLC. At $37^{\circ} \mathrm{C}$, sulpiride uptake in pH 6.0 was twice as much as in pH 7.4. At $4^{\circ} \mathrm{C}$, however, no significant difference was observed between $\mathrm{pH}$ 6.0 and 7.4. The uptake at $4^{\circ} \mathrm{C}$ was markedly lower than that obtained at $37^{\circ} \mathrm{C}$. The subtraction of the uptake at $4{ }^{\circ} \mathrm{C}$ from the uptake at $37^{\circ} \mathrm{C}$ indicated a saturable process, and the result of the Eadie-Hofstee plot analysis indicated that the uptake consists of two or more saturable components. The uptake was significantly inhibited by uncoupler, protonophore, amino acid modifying agent and proteinase. Sulpiride efflux was temperature-dependent and was significantly inhibited by uncoupler and amino acid modifying agent. These findings indicate that sulpiride uptake and efflux in Caco-2 cells are carrier-mediated. Furthermore, the uptake was significantly decreased by some substrates and inhibitors of peptide transporter, PEPT1, and organic cation transporters, OCTN1 and OCTN2, and was significantly increased by preloading with them. The uptake was also significantly increased by a typical substrate of P-glycoprotein. From these findings, we presumed that peptide transporter PEPT1 and organic cation transporters OCTN1 and OCTN2 are involved with this uptake. P-glycoprotein may also contribute to the efflux of sulpiride.
\end{abstract}

Key words sulpiride; uptake; Caco-2 cell; PEPT1; P-glycoprotein; organic cation transporter

Sulpiride (Fig. 1), [N-(1-ethyl-2-pyrrolidinyl)methyl]-2methoxy-5-sulfamoylbenzamide, is an oral selective dopamine $\mathrm{D}_{2}$ receptor antagonist, ${ }^{1,2)}$ and has a much lower incidence of extrapyramidal side effects than any other antagonists of this kind. ${ }^{3)}$ Sulpiride is widely used for treatment of schizophrenia, depression, other related psychological disorders, and gastric and duodenal ulcers. Optimization of treatment with sulpiride requires knowledge of its bioavailability, pharmacokinetics and pharmacodynamics in humans.

Sulpiride has a peptide bond in its structure (Fig. 1), and comprises two ionizable species, the nitrogen of the pyrrolidine ring $\left(\mathrm{p} K_{\mathrm{a} 1}\right.$ 8.99) and the sulphamoyl group $\left(\mathrm{p} K_{\mathrm{a} 2}\right.$ 10.19). Sulpiride has a bell-shaped partition-pH profile, ${ }^{4)}$ which clearly shows that it is an extremely hydrophilic cationic species at physiological $\mathrm{pH}$ and is unlikely to be partitioned into lipophilic media. Sulpiride is believed to be transported across intestinal mucosa by a carrier-mediated process. Hydrophobic low molecules might be absorbed from the intestinal mucosa according to simple diffusion, but most compounds need a carrier protein, so-called drug transporters, for their transmembrane transport in the small intestine..$^{5-10)}$ From its chemical structure and partition-pH profile, we speculate that sulpiride is mainly transported by peptide transporters and organic cation transporters on the apical membrane. Peptide transporters PEPT1 and PEPT2 mediate the $\mathrm{H}^{+}$coupled transport of oligopeptides and peptide-like drugs, such as $\beta$-lactam antibiotics, ${ }^{11)}$ anticancer agent bestatin, ${ }^{12)}$ antiherpetic agent valacyclovir, ${ }^{13)}$ and angiotensin converting enzyme inhibitors. ${ }^{14)}$ Organic cation transporters uptake some organic cations. P-Glycoprotein, an ATP-dependent export pump, may also participate in organic cation secretion across the brush-border membrane. ${ }^{8)}$

Cells of the human colon carcinoma cell line Caco-2 have several advantages for intestinal absorption studies, because they form well-differentiated intestinal epithelial cells and show several functional properties of the small intestine, such as carrier-mediated transport systems, receptors, and many enzyme activities. ${ }^{15)}$ Caco-2 cells are also widely used to predict intestinal "in vivo" absorption in humans. ${ }^{16)}$ In this study, we investigated whether sulpiride in Caco-2 cell monolayers is transported by a carrier-mediated system.

\section{MATERIALS AND METHODS}

Materials Sulpiride, $N$-2-hydroxyethlypiperazine- $N N^{\prime}-2-$ ethanesulfonic acid (HEPES) and 2-( $N$-morpholino)ethanesulfonic acid (MES) were purchased from ICN Biomedicals Inc. (Costa Mesa, CA, U.S.A.). Carbonyl cyanide $p$-trifluoromethoxy-phenylhydrazone (FCCP), L-carnitine, glycylsarcosine, papain (from Papaya Latex), Dulbecco's modified Eagle medium (DMEM), non-essential amino acid and fetal bovine serum were purchased from Sigma (St. Louis, MO, U.S.A.). p-Aminohippuric acid, captopril, choline chloride, cyclosporin A, 2,4-dinitrophenol, nicotinic acid, quinidine and verapamil hydrochloride were purchased from Wako Pure Chemical Industries Ltd. (Osaka, Japan). Dithiothreitol and 1-naphthylamine were purchased from Kanto Chemicals (Tokyo, Japan). All other chemicals used in the experiments were of the highest purity commercially available.

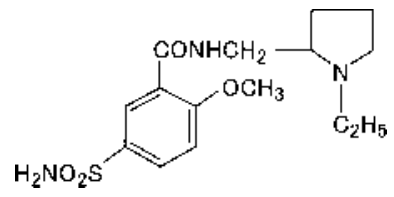

Fig. 1. Chemical Structure of Sulpiride 
HPLC Conditions HPLC was carried out using a model CCPM pump (Tosoh, Tokyo, Japan) equipped with a RF-530 fluorescence detector (Shimadzu, Kyoto, Japan). The excitation and emission wavelengths were set at 307 and $358 \mathrm{~nm}$, respectively. A reversed-phase column packed with LiChrospher 100 RP-18(e) (LiChroCART 250-4, $5 \mu \mathrm{m}, 250 \times 4 \mathrm{~mm}$ i.d., Kanto Chemical, Tokyo) was used at $50^{\circ} \mathrm{C}$. The mobile phase used a mixture of acetonitrile $/ 1 \%$ triethanolamine $/ 6$ $\mathrm{mM} \mathrm{H}_{3} \mathrm{PO}_{4}(3 / 0.3 / 3, \mathrm{v} / \mathrm{v} / \mathrm{v})$. The flow rate is shown in Fig. 2. Calibration curves were obtained by injecting sulpiride (2$4000 \mathrm{ng}$ ) containing a quantitative amount $(300 \mathrm{ng})$ of 1-naphytylamine as an internal standard into the HPLC system.

Cell Culture Caco- 2 cells in passage 41 were obtained from the RIKEN Gene Bank (Tsukuba, Japan). The cells in passages $45-55$ were grown routinely on $50 \mathrm{ml}$ plastic culture flasks (Becton Dickinson, Franklin, NJ, U.S.A.) in DMEM containing $10 \%$ fetal bovine serum, $1 \%$ non-essential amino acid, streptomycin $(100 \mu \mathrm{g} / \mathrm{ml})$ and penicillin $\mathrm{G}$ $(100 \mathrm{U} / \mathrm{ml})$ at $37^{\circ} \mathrm{C}$ in a $5 \% \mathrm{CO}_{2} / 95 \%$ air atmosphere. The medium was replaced every $3-4 \mathrm{~d}$ after inoculation. The subculture was carried out every $6 \mathrm{~d}$ using $0.02 \% \mathrm{EDTA} /$ $0.25 \%$ trypsin. For the uptake and efflux study, Caco- 2 cells were seeded at a density of $8 \times 10^{5}$ cells/dish on $60 \mathrm{~mm}$ plastic culture dishes (Becton Dickinson). Caco-2 cell monolayers were used on the 5th day for the experiments.

Uptake, Efflux and trans-Stimulation Study For the uptake studies, the culture medium was removed, and Caco-2 cell monolayers were washed twice with incubation medium consisting of $145 \mathrm{~mm} \mathrm{NaCl}, 3 \mathrm{mM} \mathrm{KCl}, 1 \mathrm{~mm} \mathrm{CaCl}, 0.5 \mathrm{~mm}$ $\mathrm{MgCl}_{2}, 5 \mathrm{~mm}$ D-glucose, $5 \mathrm{~mm}$ HEPES (pH 7.4) or $5 \mathrm{~mm}$ MES $\left(\mathrm{pH}\right.$ 6.0). ${ }^{17)}$ After the wash, Caco-2 cell monolayers were preincubated with $3 \mathrm{ml}$ of the incubation medium for $10 \mathrm{~min}$ at $37^{\circ} \mathrm{C}$. The incubation medium was removed after the preincubation, and Caco- 2 cell monolayers were incubated with $3 \mathrm{ml}$ of fresh incubation medium containing sulpiride in the presence or absence of other compounds for the time indicated at $4^{\circ} \mathrm{C}$ or $37^{\circ} \mathrm{C}$. Sulpiride was dissolved in dimethyl sulfoxide (DMSO), and other compounds were dissolved in DMSO or $\mathrm{H}_{2} \mathrm{O}$. The final concentration of DMSO in the incubation medium was $1 \%$. The uptake was terminated by aspiration of the medium, and Caco-2 cell monolayers were washed twice with ice-cold incubation medium. To measure the amount of sulpiride, an internal standard (1-naphthyamine, 1 or $2.5 \mu \mathrm{g} / 50 \mu \mathrm{l}$ ) was added to Caco- 2 cell monolayers, which were then scraped using a cell scraper (Becton Dickinson) with $2 \mathrm{ml}$ of $0.2 \mathrm{M} \mathrm{Na} \mathrm{CO}_{3} / \mathrm{NaHCO}_{3}$ buffer ( $\mathrm{pH}$ 9.8), and were then homogenized at $23000 \mathrm{rpm}$ for $30 \mathrm{~s}$ using an Omni type $\mu \mathrm{H}$ homogenizer (St. Louis, MO, U.S.A.). An aliquot of the homogenate was extracted with $5 \mathrm{ml}$ chloroform, and $4 \mathrm{ml}$ of the organic layer was evaporated to give the residue. The residue was dissolved in the mobile phase and subjected to the HPLC system. The protein concentrations of cells solubilized in $0.2 \mathrm{M} \mathrm{Na} \mathrm{CO}_{3} / \mathrm{NaHCO}_{3}$ buffer ( $\mathrm{pH}$ 9.8) were measured by the method of Lowry et al. ${ }^{18}$ ) using a Bio-Rad Protein Assay Kit (Bio-Rad, Richmond, CA, U.S.A.) with bovine serum albumin as the reference.

For the efflux studies, Caco-2 cell monolayers were incubated with sulpiride for $30 \mathrm{~min}$ at $37^{\circ} \mathrm{C}$, and were washed twice with ice-cold incubation medium. Caco- 2 cell monolayers were then incubated at $4{ }^{\circ} \mathrm{C}$ or $37^{\circ} \mathrm{C}$ for the time indicated in incubation medium with or without compounds.
After aspirating the medium and washing the monolayers with ice-cold medium, the monolayers were used to measure sulpiride as described above.

For the trans-stimulation study, Caco-2 cell monolayers were preloaded with various compounds for $30 \mathrm{~min}$ at $37^{\circ} \mathrm{C}$, and were washed twice with ice-cold incubation medium. Caco-2 cell monolayers were then incubated with sulpiride for $10 \mathrm{~min}$ at $37^{\circ} \mathrm{C}$, and then the amounts of sulpiride in the monolayers were measured as described above.

Statistical Analysis The results are expressed as the mean \pm S.D. Differences between two groups were evaluated using the Student's $t$-test or Welch's $t$-test after the initial analysis of $F$-test. Three or more groups were evaluated using the Bonferroni/Dunn multiple comparison test or Scheffe's multiple comparison test after analysis of the Bartlett test and one-way analysis of variance test. $p$ values less than 0.05 were considered significant.

\section{RESULTS}

HPL Chromatogram Obtained from Caco-2 Cell Monolayers Extract Several HPLC methods to measure sulpiride have been described previously. ${ }^{19,20)}$ The fluorescence detection-HPLC method seems to be more specific and selective than the other HPLC methods. Figure 2 shows typical HPL chromatograms from the analysis of incubated samples. The minimum detection limit for sulpiride was $1.0 \mathrm{ng} /$ injection. A known amount $(3,10,30 \mu \mathrm{g})$ of sulpiride was added to the cell homogenates, and sulpiride recovered by the extraction procedure was measured. The recovery $(>95 \%)$ of sulpiride was satisfactory. Only peaks of sulpiride and 1-naphythylamine (internal standard) and unknown peak c were observed

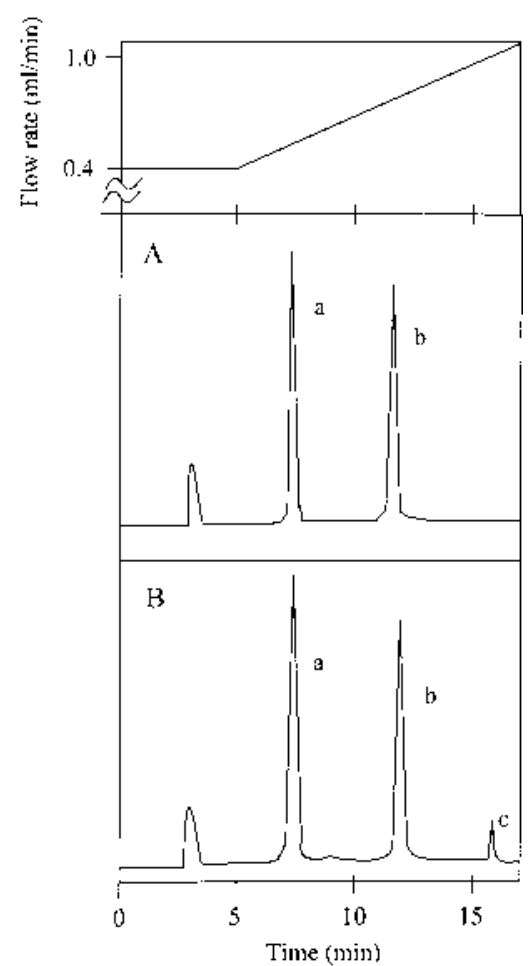

Fig. 2. HPL Chromatograms Showing the Separation of Compounds and the Flow Rate

(A) Authentic compounds. (B) Extract obtained from Caco-2 cell monolayers. Peaks: $\mathrm{a}=$ sulpiride, $\mathrm{b}=1$-naphthylamine (internal standard), $\mathrm{c}=$ unknown peak. 


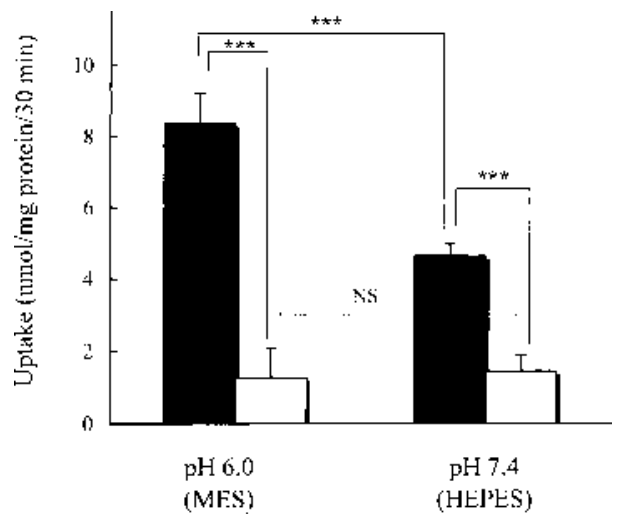

Fig. 3. Sulpiride Uptake at $\mathrm{pH} 6.0$ and $\mathrm{pH} 7.4$ in Caco-2 Cell Monolayers Caco-2 cell monolayers were incubated with sulpiride $(0.1 \mathrm{~mm})$ for $30 \mathrm{~min}$ at $4{ }^{\circ} \mathrm{C}$ ( $\square$ ) or $37^{\circ} \mathrm{C}(\square)$. Each column represents the mean \pm S.D. of $4-5$ monolayers. Significant differences between the two groups, $* * * p<0.001$. NS: Not significantly different.

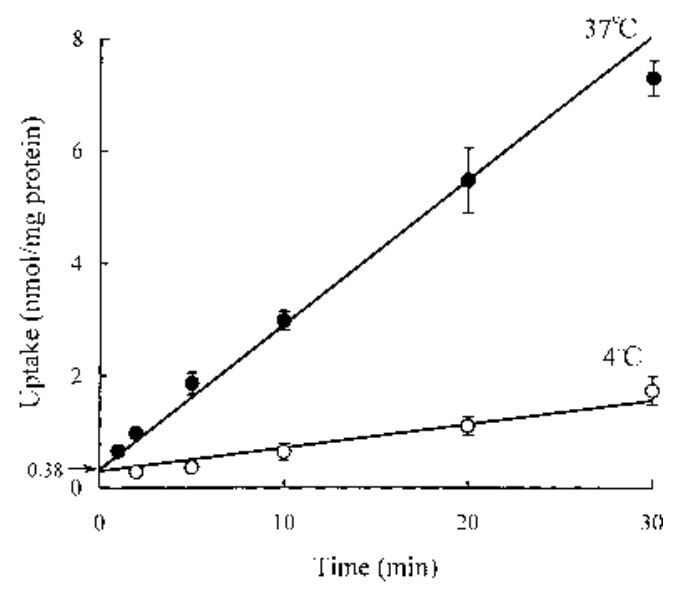

Fig. 4. Time Courses of Sulpiride Uptake in Caco-2 Cell Monolayers

Caco-2 cell monolayers were incubated with sulpiride $(0.1 \mathrm{~mm})$ at $4^{\circ} \mathrm{C}$ or $37^{\circ} \mathrm{C}$. Each value represents the mean \pm S.D. of 4 monolayers.

in the HPL chromatogram of the extracts (Fig. 2).

Effects of pH, Incubation Time and Sulpiride Concentration on Sulpiride Uptake We first investigated the effects of $\mathrm{pH}$, incubation time and sulpiride concentration on sulpiride uptake at $4{ }^{\circ} \mathrm{C}$ or $37^{\circ} \mathrm{C}$. Figure 3 shows the effects of the medium $\mathrm{pH}$ on sulpiride uptake. In Caco-2 cell monolayers, sulpiride uptake at both $\mathrm{pH} 6.0$ and $\mathrm{pH} 7.4$ at $37^{\circ} \mathrm{C}$ was higher than at $4^{\circ} \mathrm{C}$, and at $\mathrm{pH} 6.0$ was significantly higher than at $\mathrm{pH} 7.4$ at $37^{\circ} \mathrm{C}$. Therefore, we conducted the following experiments using a medium at $\mathrm{pH}$ 6.0.

Figure 4 shows the time courses for sulpiride uptake across Caco-2 cells. Sulpiride uptake at $37^{\circ} \mathrm{C}$ increased rapidly and almost linearly for $30 \mathrm{~min}$. When Caco- 2 cell monolayers were incubated at $4{ }^{\circ} \mathrm{C}$, sulpiride uptake was linear, and it was far smaller than that at $37^{\circ} \mathrm{C}$ up to $30 \mathrm{~min}$. We thereafter subtracted the intersection value $(0.38 \mathrm{nmol} / \mathrm{mg}$ protein) on the Y-axis, as the non-specific binding amount from sulpiride uptake. Sulpiride uptake was apparently linear for $20 \mathrm{~min}$, and therefore further studies were performed at $10 \mathrm{~min}$.

One piece of important evidence of the carrier-mediated uptake is saturation of the uptake rate. Thus, we investigated the effect of substrate concentration on the uptake in Caco-2 cell monolayers. Sulpiride uptake at $37^{\circ} \mathrm{C}$ was nonlinear,

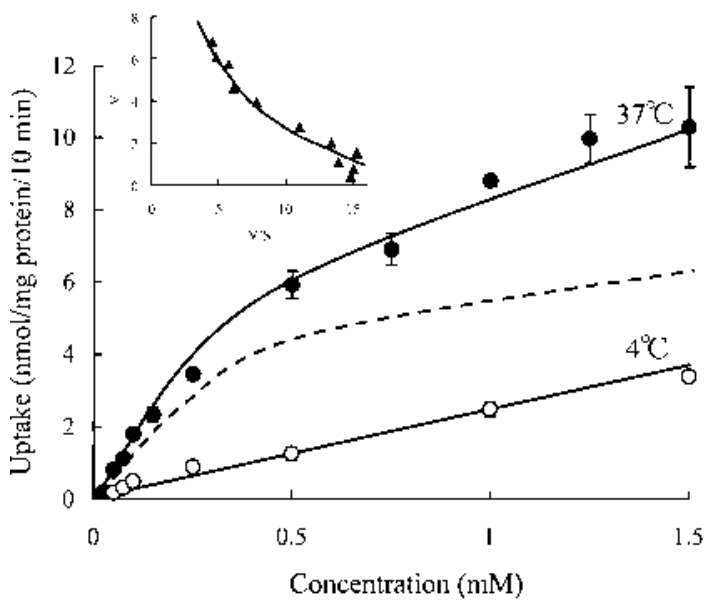

Fig. 5. Concentration Dependency of Sulpiride Uptake in Caco-2 Cell Monolayers

Caco-2 cell monolayers were incubated with sulpiride $(0.025-1.5 \mathrm{~mm})$ for $10 \mathrm{~min}$ at $4{ }^{\circ} \mathrm{C}$ or $37^{\circ} \mathrm{C}$. The dashed line represents the difference of sulpiride uptake between $4{ }^{\circ} \mathrm{C}$ and $37^{\circ} \mathrm{C}$, and the inset shows the Eadie-Hofstee plot of sulpiride uptake after the subtraction. Each value represents the mean \pm S.D. of 4 monolayers.

Table 1. Effects of Metabolic Inhibitors, Amino Acid Modifying Reagent and Proteinase on Sulpiride Uptake in Caco-2 Cell Monolayers

\begin{tabular}{|c|c|c|c|}
\hline Compound & $\begin{array}{l}\text { Concentration } \\
(\mathrm{mm})\end{array}$ & $\begin{array}{c}\text { Uptake } \\
(\mathrm{nmol} / \mathrm{mg} \\
\text { protein } / 10 \mathrm{~min})\end{array}$ & $\%$ of control \\
\hline \multicolumn{4}{|l|}{ Experiment $1^{a}$ ) } \\
\hline Control & - & $1.85 \pm 0.23$ & 100 \\
\hline 2,4-Dinitrophenol & 1.0 & $1.00 \pm 0.13 * * *$ & 54 \\
\hline FCCP & 0.1 & $1.21 \pm 0.10^{* *}$ & 65 \\
\hline Dithiothreitol & 1.0 & $0.96 \pm 0.07 * * *$ & 52 \\
\hline \multicolumn{4}{|l|}{ Experiment $2^{b)}$} \\
\hline Control & - & $1.84 \pm 0.11$ & 100 \\
\hline Papain & $0.5 \mathrm{mg} / \mathrm{ml}$ & $0.92 \pm 0.12 * * *$ & 50 \\
\hline
\end{tabular}

a) Caco-2 cell monolayers were preincubated with or without various compounds at $37^{\circ} \mathrm{C}$ for $10 \mathrm{~min}$. b) Caco- 2 cell monolayers were preincubated with or without activated papain in $50 \mathrm{~mm}$ phosphate buffer ( $\mathrm{pH}$ 6.2) containing $5 \mathrm{~mm}$ cysteine and $2 \mathrm{~mm}$ EDTA at $37^{\circ} \mathrm{C}$ for $10 \mathrm{~min}$. After the preincubation, the monolayers were incubated with sulpiride $(0.1 \mathrm{~mm})$ at $37^{\circ} \mathrm{C}$ for $10 \mathrm{~min}$. Each value represents the mean \pm S.D. of 4 monolayers. Significantly different from the respective control, $* * p<0.01$, $* * * p<0.001$. FCCP: carbonyl cyanide $p$-trifluoromethoxy-phenylhydrazone.

whereas the uptake at $4{ }^{\circ} \mathrm{C}$ was linear (Fig. 5). The uptake at $37^{\circ} \mathrm{C}$ could be expressed by the sum of simple diffusion and carrier-mediated uptake, while the uptake at $4{ }^{\circ} \mathrm{C}$ could be expressed by simple diffusion uptake. Subtraction of the uptake at $4{ }^{\circ} \mathrm{C}$ from the uptake at $37^{\circ} \mathrm{C}$ showed a saturation curve. The Eadie-Hofstee plot of the data after the correction is shown in the inset of Fig. 5 and indicates a nonlinearity.

Effect of Metabolic Inhibitors, Amino Acid Modifying Reagent and Proteinase The effects of metabolic inhibitors, amino acid modifying reagent and proteinase on the uptake of sulpiride were studied to determine out whether this uptake requires cellular energy expenditure, as summarized in Table 1. We adopted two conditions (experiments 1, 2) in this study, because the preincubation conditions were different depending on the compound tested. The metabolic inhibitors 2,4-dinitrophenol and FCCP inhibited the uptake of sulpiride in Caco-2 cell monolayers, as did dithiothreitol and papain.

Sulpiride Efflux from Caco-2 Cell Monolayers After Caco-2 cell monolayers were incubated with sulpiride 


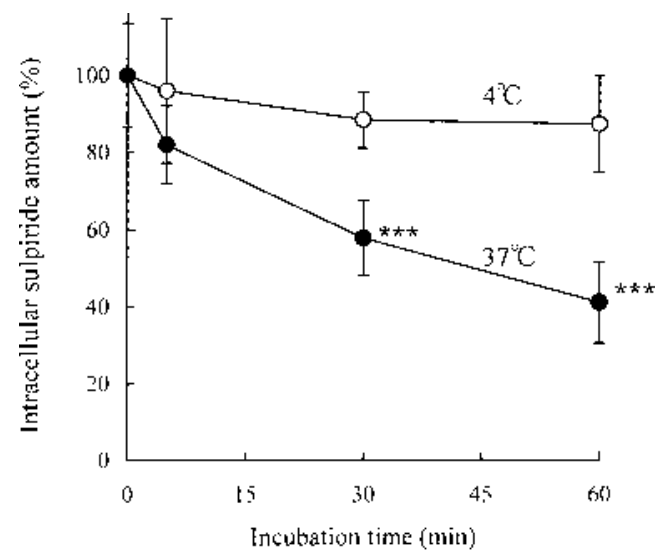

Fig. 6. Time Courses of Sulpiride Efflux from Caco-2 Cell Monolayers

After Caco-2 cell monolayers were incubated with sulpiride $(0.1 \mathrm{~mm})$ at $37^{\circ} \mathrm{C}$ for $30 \mathrm{~min}$, the monolayers were incubated at $4{ }^{\circ} \mathrm{C}$ or $37^{\circ} \mathrm{C}$ in incubation medium with no compounds. Each value represents the mean \pm S.D. of $4-8$ monolayers. Significant differences between the two groups, $* * * p<0.001$.

Table 2. Effects of Metabolic Inhibitor and Amino Acid Modifying Reagent on Sulpiride Efflux from Caco-2 Cell Monolayers

\begin{tabular}{|c|c|c|}
\hline \multirow{2}{*}{ Compound } & \multicolumn{2}{|c|}{ Intracellular sulpiride amount (\%) } \\
\hline & $30 \mathrm{~min}$ & $60 \mathrm{~min}$ \\
\hline Control & $51.6 \pm 4.2$ & $32.7 \pm 2.0$ \\
\hline 2,4-Dinitrophenol & $69.7 \pm 4.7 * *$ & $44.1 \pm 2.2 * * *$ \\
\hline Dithiothreitol & $64.8 \pm 3.3 * *$ & $53.4 \pm 3.8 * * *$ \\
\hline
\end{tabular}

Caco- 2 cell monolayers were preincubated with sulpiride $(0.1 \mathrm{mM})$ at $37^{\circ} \mathrm{C}$ for $30 \mathrm{~min}$. After the preincubation, monolayers were incubated with or without 2,4-dinitrophenol and dithiothreitol. Each value represents the mean \pm S.D. of 4 monolayers. Significantly different from the control, $* * p<0.01, * * * p<0.001$.

$(0.1 \mathrm{~mm})$ at $37^{\circ} \mathrm{C}$ for $30 \mathrm{~min}$, the monolayers were incubated at $4{ }^{\circ} \mathrm{C}$ or $37^{\circ} \mathrm{C}$ with no compounds. Figure 6 shows the percentage of intracellular sulpiride amount at the indicated times. The decrease of intracellular sulpiride amount at $37^{\circ} \mathrm{C}$ was time-dependent, showing a decrease of $58 \%$ at $60 \mathrm{~min}$. However, when the monolayers were incubated at $4{ }^{\circ} \mathrm{C}$, the intracellular sulpiride amount was only slightly decreased.

The effects of 2,4-dinitrophenol and dithiothreitol on sulpiride efflux were investigated. As shown in Table 2, the intracellular sulpiride amount was significantly increased by 2,4-dinitrophenol and dithiothreitol treatment; these compounds thus inhibited sulpiride efflux in Caco- 2 cell monolayers.

Effect of Various Substrates and Inhibitors of Intestinal Drug Transporters on Sulpiride Uptake in Caco-2 Cell Monolayers Table 3 shows the inhibitory effects of various well-known substrates of intestinal drug transporters on sulpiride uptake in Caco-2 cell monolayers. The uptake was significantly inhibited by incubation with captopril, glycylsarcosine, L-carnitine and choline, while it significantly increased by incubation with cyclosporin A. Due to the limited solubility of cyclosporin A in the incubation medium, the concentration used was low $(0.03 \mathrm{~mm})$ in the experiment with this compound. Guanidine, nicotinic acid, $p$-aminohippuric acid, quinidine and verapamil had no significant effect.

trans-Stimulation Effect of Various Substrates and Inhibitors of Intestinal Drug Transporters on Sulpiride
Table 3. Effects of Various Substrates and Inhibitors of Intestinal Drug Transporters on Sulpiride Uptake in Caco-2 Cell Monolayers

\begin{tabular}{lccc}
\hline \hline \multicolumn{1}{c}{ Compound } & $\begin{array}{c}\text { Concentration } \\
(\mathrm{mm})\end{array}$ & $\begin{array}{c}\text { Uptake } \\
(\mathrm{nmol} / \mathrm{mg} \\
\text { protein/10 min })\end{array}$ & \% of control \\
\hline Control & - & $1.99 \pm 0.07$ & 100 \\
Captopril & 0.1 & $1.48 \pm 0.18^{* *}$ & 76 \\
& 1.0 & $1.22 \pm 0.19^{* * *}$ & 62 \\
Glycylsarcosine & 0.1 & $1.53 \pm 0.19^{* *}$ & 78 \\
& 1.0 & $1.27 \pm 0.14^{* * *}$ & 65 \\
L-Carnitine & 0.1 & $1.65 \pm 0.11^{* *}$ & 85 \\
& 1.0 & $1.37 \pm 0.06^{* * *}$ & 70 \\
Choline & 0.1 & $1.71 \pm 0.12^{*}$ & 88 \\
& 1.0 & $1.49 \pm 0.07^{* * *}$ & 76 \\
Guanidine & 0.1 & $1.84 \pm 0.22$ & 94 \\
& 1.0 & $1.79 \pm 0.14$ & 92 \\
Nicotinic acid & 0.1 & $1.86 \pm 0.07$ & 93 \\
& 1.0 & $1.87 \pm 0.14$ & 94 \\
p-Aminohippuric acid & 0.1 & $1.79 \pm 0.15$ & 90 \\
Quinidine & 1.0 & $1.85 \pm 0.17$ & 93 \\
& 0.1 & $2.07 \pm 0.10$ & 104 \\
Verapamil & 1.0 & $1.85 \pm 0.22$ & 93 \\
& 0.1 & $2.05 \pm 0.16$ & 103 \\
Cyclosporin A & 1.0 & $1.74 \pm 0.22$ & 88 \\
& 0.03 & $2.19 \pm 0.22^{*}$ & 112 \\
\hline
\end{tabular}

Caco-2 cell monolayers were incubated with sulpiride $(0.1 \mathrm{~mm})$ at $37^{\circ} \mathrm{C}$ for $10 \mathrm{~min}$ in presence or absence of various compounds. Each value represents the mean \pm S.D. of $4-8$ monolayers. Significantly different from the control, $* p<0.05, * * p<0.01$, $* * * p<0.001$

Table 4. trans-Stimulation Effects of Various Substrates and Inhibitors of Intestinal Drug Transporters on Sulpiride Uptake in Caco-2 Cell Monolayers

\begin{tabular}{lccc}
\hline \hline Compound & $\begin{array}{c}\text { Concentration } \\
(\mathrm{mm})\end{array}$ & $\begin{array}{c}\text { Uptake } \\
(\mathrm{nmol} / \mathrm{mg} \\
\text { protein/10 min })\end{array}$ & \% of control \\
\hline Control & - & $1.91 \pm 0.14$ & 100 \\
Captopril & 1.0 & $2.52 \pm 0.25^{* * *}$ & 132 \\
Glycylsarcosine & 1.0 & $2.58 \pm 0.18^{* * *}$ & 135 \\
L-Carnitine & 1.0 & $2.28 \pm 0.13^{* *}$ & 119 \\
Choline & 1.0 & $2.25 \pm 0.09^{* *}$ & 118 \\
Guanidine & 1.0 & $1.90 \pm 0.16$ & 100 \\
Nicotinic acid & 1.0 & $1.82 \pm 0.13$ & 95 \\
$p$-Aminohippuric acid & 1.0 & $1.90 \pm 0.13$ & 99
\end{tabular}

Caco-2 cell monolayers were preloaded with various compounds $(1.0 \mathrm{~mm})$ at $37^{\circ} \mathrm{C}$ for $30 \mathrm{~min}$. After the preincubation, the monolayers were incubated with sulpiride $(0.1 \mathrm{~mm})$ at $37^{\circ} \mathrm{C}$ for $10 \mathrm{~min}$. Each value represents the mean \pm S.D. of $4-8$ monolayers. Significantly different from the control, $* * p<0.01, * * * p<0.001$.

Uptake in Caco-2 Cell Monolayers We investigated the trans-stimulation effects of various well-known substrates of intestinal drug transporters on sulpiride uptake in Caco-2 cell monolayers. The uptake was significantly stimulated by preloading with captopril, glycylsarcosine, L-carnitine and choline (Table 4). However, the trans-stimulation effect was not observed by preloading with guanidine, nicotinic acid or $p$-aminohippuric acid.

\section{DISCUSSION}

The benzamide agent, sulpiride, is a selective antagonist of the dopamine $\mathrm{D}_{2}$ receptor. ${ }^{1,2)}$ Sulpiride is widely used for treatment of schizophrenia $(400-1800 \mathrm{mg} / \mathrm{d})$, depression $(50-300 \mathrm{mg} / \mathrm{d})$ and gastric and duodenal ulcers $(150 \mathrm{mg} / \mathrm{d})$. This agent has a much lower incidence of extrapyramidal 
side effects. Maintaining an effective blood concentration is important from the viewpoint of the pharmacological action of sulpiride. The bioavailability of sulpiride is low in some species, a mean of $27 \%$ in the human and $15-20 \%$ in the rat, while it is relatively large $(44-85 \%)$ in the dog. ${ }^{19,21)}$ The low bioavailability in the human was probably due to poor absorption. ${ }^{21)}$ The mechanism of gastrointestinal absorption of sulpiride, however, has not been examined in detail.

In this study, we first investigated whether sulpiride was incorporated into Caco-2 cell monolayers via the carrier-mediated uptake system. The results are summarized as follows: (1) Sulpiride uptake was temperature dependent. At $37^{\circ} \mathrm{C}$, sulpiride uptake at $\mathrm{pH} 6.0$ was greater than that at $\mathrm{pH} 7.4$. At $4^{\circ} \mathrm{C}$, however, no significant difference was observed between the two $\mathrm{pH}$, and the uptake at this temperature was markedly lower than that obtained at $37{ }^{\circ} \mathrm{C}$ (Figs. 3, 4). (2) With sulpiride concentration dependency, the subtraction of sulpiride uptake at $4{ }^{\circ} \mathrm{C}$ from the uptake at $37^{\circ} \mathrm{C}$ indicated a saturable process (Fig. 5). Furthermore, the Eadie-Hofstee plot of the saturable process indicates that the uptake consists of two or more saturable components. (3) Sulpiride uptake was inhibited by an uncoupling agent of oxidative phosphorylation, 2,4-dinitrophenol, and by a protonophore, FCCP. Sulpiride uptake was also inhibited by an amino acid modifying agent, dithiothreitol, and by a proteinase, papain (Table 1). From these results, sulpiride uptake into Caco-2 cells is believed to be dependent on cellular energy expenditure and proton gradient, and that two or more carriers are concerned in at least part of the sulpiride uptake into Caco-2 cells.

In the efflux experiment (Fig. 6), the intracellular sulpiride amount was about $40 \%$ by $60 \mathrm{~min}$ at $37^{\circ} \mathrm{C}$. However, the decrease in the intracellular sulpiride amount was slight, and was about $90 \%$ by $60 \mathrm{~min}$ at $4{ }^{\circ} \mathrm{C}$. In addition, 2,4-dinitrophenol and dithiothreitol inhibited the efflux of sulpiride (Table 2). These findings suggest the existence of a carriermediated secretory system for sulpiride in Caco-2 cells. Caco-2 cells highly express P-glycoprotein, and the P-glycoprotein secretes cationic and hydrophobic compounds. ${ }^{22,23)}$ The secretion of sulpiride in Caco-2 cells might be mediated by a specific transport process such as P-glycoprotein.

As it is suggested that a carrier-mediated process contributes to the sulpiride uptake into Caco-2 cell monolayers, we performed cis-inhibition studies to obtain more information about the identity of the transporter(s). As shown in Table 3, sulpiride uptake was inhibited by peptide transporter PEPT1 substrates, captopril ${ }^{14)}$ and glycylsarcosine, ${ }^{11)}$ and organic cation transporter OCTN1 and OCTN2 substrate and inhibitor, L-carnitine ${ }^{7)}$ and choline, ${ }^{24,25)}$ respectively. Conversely, the uptake was increased by a typical P-glycoprotein substrate, cyclosporin A. ${ }^{26}$ ) Moreover, sulpiride uptake was significantly accelerated by preloading with captopril, glycylsarcosine, L-carnitine and choline (Table 4). That is, with the uptake of sulpiride in Caco-2 cell monolayers, the trans-stimulation effect was observed by captopril, glycylsarcosine, Lcarnitine and choline. Stimulation on the uptake of a particular molecule by preincubation or preloading with a structural analogue has also been observed in other systems, such as organic anion transporters, ${ }^{27,28)}$ organic cation transporters $^{22,29)}$ and peptide transporters. ${ }^{30)}$ In the present study, however, no significant stimulation was observed by preloading with organic cation transporter OCT3 substrate, guani- dine,${ }^{31)}$ or organic anion transporter MCT1 and/or AE2 substrates, nicotinic acid $^{32,33)}$ and $p$-aminohippuric acid. ${ }^{34,35)} \mathrm{P}$ Glycoprotein, and organic cation transporter OCTN1 and OCTN2 substrates, quinidine ${ }^{36)}$ and verapamil ${ }^{36)}$ also had no significant effect. We speculated that this was because of the simultaneous inhibition of sulpiride uptake and efflux by these compounds. From these findings, we presumed that peptide transporter PEPT1 and organic cation transporters OCTN1 and OCTN2 take part in carrier-mediated sulpiride uptake, and that P-glycoprotein takes part in carrier-mediated sulpiride efflux. Recently, Baluom et al. ${ }^{37)}$ reported that sulpiride intestinal absorption was increased when administered together with the P-glycoprotein inhibitors in rat intestine. They suggest that intestinal P-glycoprotein efflux is the cause of poor sulpiride bioavailability after oral administration. To clarify the specific transport process by which it takes part in the secretion of sulpiride will require further studies using transcellular transport systems.

In conclusion, not only the nonsaturable process but also the saturable one mediates sulpiride uptake into Caco- 2 cells. This study shows the first evidence that sulpiride uptake in Caco-2 cells is carrier-mediated, and that peptide transporters and organic cation transporters are involved in the uptake. Pglycoprotein may also contribute to the secretion of sulpiride in Caco-2 cells. Studies using Caco-2 cells cultured on permeable membrane can furnish further information on transport mechanism of sulpiride across the cells. In a future paper, we will report on the transcellular transport of sulpiride using Caco-2 cell monolayers cultured on permeable membrane.

\section{REFERENCES}

1) Trabucchi M., Longoni R., Fresia P., Spano P. F., Life Sci., 17, 15511556 (1975).

2) Jenner P., Marsden C. D., Neuropharmacology, 20, 1285-1293 (1981).

3) Kohri N., Naasani I., Iseki K., Miyazaki K., J. Pharm. Pharmacol., 48, 371-374 (1996).

4) Naasani I., Kohri N., Iseki K., Miyazaki K., J. Pharm. Pharmacol., 47, 469-473 (1995).

5) Tsuji A., Tamai I., Pharm. Res., 13, 963 -977 (1996).

6) Oh D. M., Han H. K., Amidon, G. L., Pharm. Biotechnol., 12, 59-88 (1999).

7) Endou H., Folia Pharmacol. Jpn., 116, 114-124 (2000).

8) Koepsell H., Annu. Rev. Physiol., 60, 243-266 (1998).

9) Meredith D., Boyd C. A. R., Cell. Mol. Life Sci., 57, 754-778 (2000).

10) Lee V. H. L., Eur. J. Pharm. Sci., 11 (Suppl. 2), S41-S50 (2000).

11) Terada T., Saito H., Inui K., J. Biol. Chem., 273, 5582-5585 (1998).

12) Saito H., Terada T., Okuda M., Sasaki S., Inui K., Biochim. Biophys. Acta, 1280, 173-177 (1996).

13) Balimane P. V., Tamai I., Guo A., Nakanishi T., Kitada H., Leibach F. H., Tsuji A., Sinko P. J., Biochem. Biophys. Res. Commun., 250, $246-$ 251 (1998).

14) Boll M., Markovich D., Weber W. M., Korte H., Daniel H., Murer H., Pflugers Arch., 429, 146-149 (1994).

15) Tsuji A., Takanaga H., Tamai I., Terasaki T., Pharm. Res., 11, 30-37 (1994).

16) Artursson P., Karlsson J., Biochem. Biophys. Res. Commun., 175, $880-885$ (1991).

17) Terada T., Sawada K., Saito H., Hashimoto Y., Inui K., Eur. J. Pharmacol., 392, 11-17 (2000).

18) Lowry O. H., Rosebrough N. J., Farr A. L., Randall R. J., J. Biol. Chem., 193, 265-275 (1951).

19) Mizuno N., Morita E., Nishikata M., Shinkuma D., Yamanaka Y., Arch. Int. Pharmacodyn. Ther, 283, 30-38 (1986).

20) Yamada I., Mizuta H., Ogawa K., Tahara T., Chem. Pharm. Bull., 38, 
$2552-2555(1990)$

21) Bateman D. N., Adv. Biochem. Psychopharmacol., 35, 143-162 (1982).

22) Mizuuchi H., Katsura T., Hashimoto Y., Inui K., Pharm. Res., 17, $539-545$ (2000).

23) Nakayama A., Saitoh H., Oda M., Takada M., Aungst B. J., Eur. J. Pharm. Sci., 11, 317-324 (2000).

24) Wu X., Huang W., Prasad P. D., Seth P., Rajan D. P., Leibach F. H., Chen J., Conway S. J., Ganapathy V., Pharmacology, 290, 1482-1492 (1999).

25) Yabbuchi H., Tamai I., Nezu J., Sakamoto K., Oku A., Shimane M., Sai Y., Tsuji A., J. Pharmacol. Exp. Ther, 289, 768-773 (1999).

26) Saeki T., Ueda K., Tanagawara Y., Hori R., Komano T., J. Biol. Chem., 268, 6077-6080 (1993).

27) Takeuchi A., Masuda S., Saito H., Hashimoto Y., Inui K., J. Pharmacol. Exp. Ther., 293, 1034-1039 (2000).

28) Uwai Y., Saito H, Hashimoto Y., Inui K., Eur. J. Pharmacol., 398, 193-197 (2000).
29) Zhang L., Gorset W., Dresser M. J., Giacomini K. M., J. Pharmacol. Exp. Ther, 288, 1192-1198 (1999).

30) Fujita T., Morishita Y., Ito H., Kuribayashi D., Yamamoto A., Muranishi S., Life Sci., 61, 2455-2465 (1997).

31) Kekuda R., Prasad P. D., Wu P., Wang H., Fei Y. J., Leibach F. H., Ganapathy V., J. Biol. Chem., 273, 15971-15979 (1998).

32) Tamai I., Yakugaku Zasshi, 117, 415-434 (1997).

33) Yabuuchi H., Tamai I., Sai Y., Tsuji A., Pharm. Res., 15, 411-416 (1998).

34) Weinberg S. L., Burckhardt G., Wilsom F. A., J. Clin. Invest., 78, 44 50 (1986).

35) Leier I., Hummel-Eisenbeiss J., Cui Y., Keppler D., Kidney Int., 57, 1636 - 1642 (2000).

36) Wandel C., Kim R. B., Kajiji S., Guengerich F. P., Wilkinson G. R., Wood A. J., Cancer Res., 59, 3944-3948 (1999).

37) Baluom M., Friedman M., Rubinstein A., J. Contr. Rel., 70, 139-147 (2001). 